\title{
Policy Implementation Analysis on Exclusive Breastfeeding in Working Area of Cicalengka Community Health Center in Bandung Regency West Java
}

\author{
*Innana Mardhatillah, **Yaslis Ilyas \\ * Faculty of Public Health, Universitas Indonesia \\ ** Department Health Policy and Administration, Faculty of Public Health Universitas Indonesia
}

Email :innana311@gmail.com

\begin{abstract}
Data and information on the health profile of Indonesia in 2016 showed only $29.5 \%$ of infants receive exclusive breastfeeding until 6 months, the low level of exclusive breastfeeding made the government issue a regulation on exclusive breastfeeding in Government Regulation Number 33 of 2012. The study aimed to analyze the policy implementation of exclusive breastfeeding at Cicalengka Community Health Center. The study used qualitative analysis with in-depth interview method, focus group discussion and literature study. The result of this study shows that breastfeeding policy implementation in health centers is not optimal, as seen from the low coverage of exclusive breastfeeding. Socialization of the policy has not been done as a whole, the time and task division is unclear and has no special budget and the standard operating procedures is not really used in carrying out the policy. Communication is the most influential factor in the implementation of the policy. There is no support and commitment from all employees in the implementation of exclusive breastfeeding policy. The suggestion is to consistently socialize to employees and the public, carry out supervision in an effort to secure the policy, run the Standard Operating Procedure (SOP), allocate budget activities in 2018, create a memorandum of understanding with other agencies, and Self-assessment and program evaluation absolutely must do continuously.
\end{abstract}

Keywords: exclusive breastfeeding, policy implementation, community health center.

\begin{abstract}
Abstrak. Data dan informasi profil kesehatan Indonesia tahun 2016 menunjukan hanya sebesar 29,5\% bayi mendapatkan ASI Eksklusif sampai 6 bulan, rendahnya pemberian ASI Eksklusif membuat pemerintah mengeluarkan PP No. 33 Tahun 2012 tentang pemberian ASI Eksklusif. Tujuan penelitian ini untuk menganalisis implementasi kebijakan pemberian ASI Eksklusif di wilayah kerja Puskesmas Cicalengka. Penelitian menggunakan analisis kualitatif dengan metode wawancara mendalam, diskusi kelompok terarah dan studi literatur. Hasil Penelitian menemukan implementasi kebijakan pemberian ASI di puskesmas belum berjalan optimal terlihat dari cakupan pemberin ASI secara eksklusif yang masih rendah. Sosialisasi kebijakan belum dilakukan secara keseluruhan, pembagian waktu dan tugas belum jelas dan belum memiliki anggaran khusus, serta jarangnya peggunaan Standar Operasional Prosedur dalam menjalankan kebijakan. Komunikasi merupakan faktor yang paling berpengaruh terhadap implementasi kebijakan. Belum ada dukungan dan komitmen dari seluruh pegawai dalam pelaksanaan kebijakan pemberian ASI secara Eksklusif. Saran yang diajukan adalah konsisten melakukan sosialisasi kepada pegawai maupun masyarakat, dilaksanakan supervisi dalam upaya pengawalan kebijakan, menjalankan Standar Operasional Prosedur (SOP), mengalokasikan anggaran kegiatan di tahun 2018, membuat nota kesepahaman dengan instansi lain, dan self-assessment serta evaluasi program mutlak dilakukan secara kontinyu.
\end{abstract}

Kata kunci: ASI eksklusif, implementasi kebijakan, puskesmas.

\section{INTRODUCTION}

United Nation Children Fund (UNICEF) and World Health Organization (WHO) recommended that it is better that children is solely given Exclusive Breastfeeding for at least 6 (six) months in the attempt to reduce the number of illness and mortality upon babies. The addition of solid food is given after the baby is older than 6 months old, continued by breastfeeding until the children reaching 2 years old (WHO, 2015). UNICEF stated that as much as 30,000 deaths of infants in Indonesia and 10 million deaths of children in the world can be prevented through providing Exclusive Breastfeeding for six months since birth, without giving additional food or drinks to the infants every year. This matter is supported by Lancet (2010) that stated providing Exclusive Breastfeeding can lower the infant mortality rate by $13 \%$ and reduce the prevalence of stunting children.

The Infant Mortality Rate (IMR) in Indonesia is 32 deaths per 1,000 births based on Indonesian Survey of Demographic and Health (ISDH) 2012. These numbers are below the target of Millennium Development Goals (MDGs), which is 23 per 1,000 births (Depkes, 2013). 
The way of providing Exclusive Breastfeeding is one of the efforts to reach the target of IMR reduction, in order to suppress IMR and reduce 30,000 infant mortality in Indonesia and 10 million infant mortality in the world through providing Exclusive Breastfeeding for as long as six months since the first hour of birth without giving any food.

Community Nutrition Refinement Program (CNRP) in Indonesia has targeted the scope of Exclusive Breastfeeding to be $80 \%$. However, providing Exclusive Breastfeeding for six months is still too difficult to do. Government Regulation No. 33 of 2012 made by the government based on the low level of Exclusive Breastfeeding in Indonesia, in order to make the healthcare facilities and mothers to be more aware that Exclusive Breastfeeding is important and make sanctions if this policy is not implemented. The result of the research that is published by Journal Pediatrics in Ghana shows that $16 \%$ of infant mortality can be prevented by breastfeeding the infants since the first day of birth. In 42 countries show the reduction of childhood mortality rate is higher because of the Exclusive Breastfeeding which reaches 13\% compared to other public health interventions. (Roesli, 2013)

In the plan of action of the community nutrition guidance in 2010-2014, it is stated that infants aged from 0-6 months will have Exclusive Breastfeeding. This target also stated by Indonesian government since 2000 . However, in the reality by the year of 2014, the national coverage of Exclusive Breastfeeding has only reached $52,3 \%$ which has yet to reach the target. In the Province of West Java, by the year of 2013 the coverage of Exclusive Breastfeeding for infants aged 06 months is $33,7 \%$. Only one province that reached the target which is the Province of West Nusa Tenggara which is $79,7 \%$. The Province of West Java, West Papua, and North Sumatra are the three provinces with the lowest achievements. (Kemenkes, 2014)

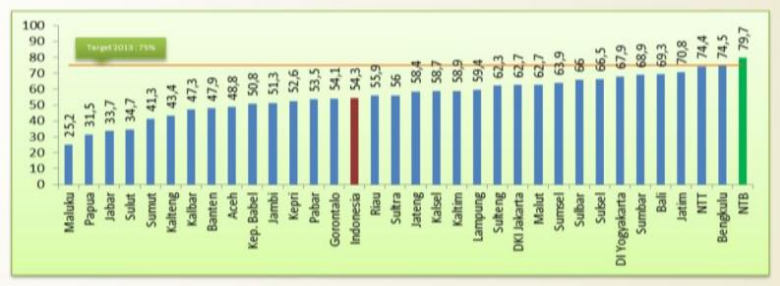

Figure 1. Coverage of Exclusive Breastfeeding 0-6 Months According to Province

Aside from that, the data and information of Indonesian Health Profile in 2016 shows the percentage of newborns given Early Breastfeeding Initiation (EBI) and Exclusive Breastfeeding: Infants aged until 6 months are 29,5\%, 0-5 months are 54\%. The ranks according to provinces put the Province of West Java in the five lowest area on Exclusive Breastfeeding coverage (Kementerian Kesehatan RI, 2017).
According to Health Profile of Cicalengka Community Health Center 2016, the percentage of Exclusive Breastfeeding for infants aged 0-6 months in the working area of Cicalengka Community Health Center in 2016 is $27 \%$. The low number of Exclusive Breastfeeding for six months is because the understanding regarding the importance of it is still low, the lack of information and knowledge of the mothers regarding the nutrition content and the advantages contained inside breast milk along with the condition of working mothers, especially the one who lives in urban area. (Dwi Sunar, 2012). According to that problem, this research is conducted to know how the Policy Implementation of Exclusive Breastfeeding in the working area of Cicalengka Community Health Center.

\section{METHOD}

This research conducts an analytical descriptive study with qualitative method through in-depth interview, Focus Group Discussion (FGD) and document search to get the depiction of policy implementation of Exclusive Breastfeeding in the working area of Cicalengka Community Health Center. The type of this research is a qualitative research with Rapid Assessment Procedure (RAP) approach. The qualitative research is a research specifically using a technique to obtain the answers or in-depth information upon opinions, perceptions, and people's feelings (Kresno, dkk, dalam Buchari, (2013)). The triangulation of sources done by gathering data from different sources which are correlated each other, while triangulation of methods done by using more than one method which is in-depth interview and Focus Group Discussion (FGD).

\section{RESULTS AND DISCUSSION}

The informants for in-depth interview are 7 people who are experienced and are on duty upon giving medical healthcare, consist of the representative of Public Health Office of Bandung Regency, Healthcare Technical Implementer Unit of Cicalengka, Puskesmas Cicalengka DTP (Cicalengka Community Health Center that provides inpatient care), Village Midwife, and Village Cadre. The educational backgrounds of the informants have been appropriate with their current positions, also, their experience in carrying out the task can be seen from their year of service which have been over 4 years. While the method of FGD is conducted to 12 civilians lives in the Cicalengka area, consist of 6 mothers that provides Exclusive Breastfeeding and 6 mothers that do not.

The policy of Exclusive Breastfeeding contains all of the conditions that regulates about Exclusive Breastfeeding in order to protect, support, and promote Exclusive Breastfeeding. This matter is in line with a global analytic comparative research upon The Policy of Breastfeeding. It concludes that the higher percentage of women giving Exclusive Breastfeeding are in the 
countries that have regulations on off work times upon the women who are doing breastfeeding. (Heymann, Raub, \& Earle, 2013).

From the result of the research, there is a Local Regulation which is one of the supports from the Local Government in implementing the national policy. The Local Regulation is written as The Local Regulation of Bandung Regency Number 8 of 2009 on Maternal, Neonatal, Infant and Child Health (MNICH) in Bandung Regency. However, this Local Regulation is not delivered equally, there are only a few informants know about this regulation. With that being said, it is needed to review how the communication works in order to socialize the policy of Exclusive Breastfeeding. This Local Regulation explains that every infant and child has the right to get Exclusive Breastfeeding for six months and breastfeeding until 2 years old.

The policy of Exclusive Breastfeeding in Indonesia gains a full support from the government, seen by the year 2012 a Government Regulation Number 33 of 2012 on Exclusive Breastfeeding was issued. It contains the conditions for the health facility, health workers, community and family to support the mothers to be able to provide Exclusive Breastfeeding. Based on the report of Provincial Health Office in 2013, the coverage of Exclusive Breastfeeding in the Province of West Java is $33,7 \%$. While the implementation of Exclusive Breastfeeding policy in Bandung Regency seen from its coverage is $31,88 \%$, and the coverage of Exclusive Breastfeeding in the working area of Cicalengka Community Health Center is $27 \%$.

\section{Depiction of Exclusive Breastfeeding}

According to Government Regulation Number 33 of 2012, Exclusive Breastfeeding is breastmilk that is given to infants since their birth until 6 months old, without adding and/or replacing with other foods and drinks. This research analyzed on what opinions came from the implementers of the policy upon the meaning of Exclusive Breastfeeding through in-depth interview with nutrition officer, managers of Mother and Child Health program, and midwife. Aside from that, the author also conducted FGD upon mothers who do Exclusive Breastfeeding as well as mothers who do not do Exclusive Breastfeeding.

This research found that there is still any perception difference of Exclusive Breastfeeding among Community Health Center officers, cadre, and mothers who do Exclusive Breastfeeding as well as who do not. The lack of knowledge of mothers about Exclusive Breastfeeding is basically reasoned, when the author asked whether the mothers have attended a counseling regarding Exclusive Breastfeeding, there were mothers that never attend it, never goes to the Community Health Center and only came to Integrated Service Post only to do weighing and then came back home.
According to Suradi (1989), one of the factors that influence the success of breastfeeding is the mother's knowledge of lactation. Someone that has knowledge about breastmilk and breastfeeding will affect the behavior that stated by the change of breastfeeding pattern towards the better.

\section{The informant's Definition of Exclusive Breastfeeding}

From the results of the FGD about the definition of Exclusive Breastfeeding from all the mothers who provide Exclusive Breastfeeding and those who do not provide Exclusive Breastfeeding, they know the meaning of Exclusive Breastfeeding, but most of them tell the definition in an incomplete way, as shown from these statements:

\section{"asi yang selama 6 bulan diberikan tanpa makanan apapun”(A4)}

(breastmilk that is given 6 months without any additional food)

\section{“asi full, asi lebih bagus daripada air tambahan" (A6)}

(full breastmilk, breastmilk is better than additional drinks)

\author{
"bagus daripada susu sapi"(B4)
} \\ (better than cow's milk)}

"Susu ibu sendiri tidak campur susu lain"(B1) (mother's milk only, without the mix of other milks)

The definition of Exclusive Breastfeeding is also put forward by a few informants when conducting in-depth interview:

“Memberikan ASI saja dari 0 sampai 6 bulan" (Z4)

(Only breastfeeding from the age of 0 to 6 months)

\begin{abstract}
"Pemberian ASI dari mulai bayinya lahir sampai dengan bayinya 6 bulan, khusus full enggak dikasih minum, enggak dikasih makan, enggak dikasih susu formula, enggak dikasih apapun selama enam bulan tanpa berhenti."'(Z6)

(Providing breastmilk since the infant was born until the age of six months, fully breastfeeding, without other drinks, without other foods, without formula milk, without any additional intake for six months without stopping)
\end{abstract}
"Banyak manfaatnya artinya ASI yang 0 bulan sampai 6 bulan"(Z7)
(Many advantages upon the breastfeeding that occurs from 0 to 6 months old)

"Pemberian ASI sampai usia 6 bulan tanpa ada makanan dan minuman pendamping seperti PASI." (Z5) 
(Breastfeeding until 6 months old without complementing foods and drinks such as Breastmilk Replacement (BR))

\section{Components of Policy Implementation}

\section{Communication}

The path of communication in delivering the information regarding Exclusive Breastfeeding policy in the working area of Cicalengka Community Health Center starts from the Exclusive Breastfeeding policy which being delivered by the Public Health Office directly to the Community Health Center and Breasfeeding Counselor through a several of medias. The communication will be effective if there are feedbacks between the receiver and the source of information. The process of communication in the effort to support the policy of Exclusive Breastfeeding can be seen in this table:

Table 2. Communication Process of the Exclusive Breastfeeding Policy

\begin{tabular}{cll}
\hline No. & \multicolumn{1}{c}{ Level } & \multicolumn{1}{c}{ Form of Communication } \\
1. & $\begin{array}{l}\text { Public } \\
\text { Health } \\
\text { Office of } \\
\text { Bandung } \\
\text { Regency }\end{array}$ & $\begin{array}{l}\text { Communication in the form of meeting with } \\
\text { the Breastfeeding Counselor in every } \\
\text { Community Health Center, through the } \\
\text { distribution of posters, Mother and Child } \\
\text { Health book, and the guidebook of Exclusive } \\
\text { Breastfeeding. }\end{array}$ \\
\hline 2. & $\begin{array}{l}\text { Community } \\
\text { Health }\end{array}$ & $\begin{array}{l}\text { Communication in the form of monthly } \\
\text { workshop meetings, cross-sector meeting, } \\
\text { disctrict coordination meeting, and counseling } \\
\text { of Exclusive Breastfeeding. }\end{array}$ \\
\hline 3. & $\begin{array}{l}\text { Integrated } \\
\text { Service Post }\end{array}$ & $\begin{array}{l}\text { Socialization and Counseling of Exclusive } \\
\text { Breastfeeding, Pregant Women Class, Class } \\
\text { of Child's Mothers, Leaflet and Mother and } \\
\text { Child Health Book Distribution }\end{array}$ \\
\hline
\end{tabular}

The policy implementation of Exclusive Breastfeeding also undergoes a transmission process through socialization. In the implementation, the socialization is conducted to all the employees, cross-sector, and the society through meetings e.g monthly workshops. The socialization is delivered by the Breasfeeding Counselor that has been trained by the Regency Health Office. Aside from that, the Breastfeeding Counselor should also advocate private companies that is in the district around the Community Health Center. According to the interview, it is known that socialization is also conducted to the level of Integrated Service Post through group counseling by the village midwives on duty because there is only one Breastfeeding Counselor in each Community Health Center. However, the village midwives have not had special training from the Breastfeeding Counselor. It is hoped that the Breastfeeding Counselor that is positioned in the Community Health Center can do socialization or training in the Community Health Center to the midwives. Aside from that, the utilization of developed media and mostly used by the society e.g flyers and social media can be a consideration for the
Community Health Center to be used as a mean of communication.

The second is clarity, the process of policy transmission should be accompanied with the clarity of information so that the policy that has been transmitted can be received clearly so that the policy implementor can know the intents, goals, and objectives of the policy. The obscurity of information will hamper the policy implementation (Ratri, 2014). Until now, the process of information delivery is clear enough delivered by the field worker even though not all implementers have that information. The socialization is conducted tiered through internal meetings and trainings.

Third is consistency. The work instructions should be consistent so that the process of policy implementation would be quicker and more effective. The inconsistency of instructions will make the tendency of the field workers to take loose actions in implementing the policy (Ratri, 2014). This matter is seen in the data stated by different informants regarding the received information and the coverage of breastfeeding that is still low.

Communication will be considered as effective when the communicated information reached the destination as expected by the communicator. The knowledge of implementors upon the content of the policy will improve automatically if the communication goes effectively. An effective communication amongst the implementors that mastering the content of the policy will affect on the attitude of the implementers of the program that will eventually affect the performance of the policy (Sudarwati, 2012). It can be concluded that communication about the Exclusive Breastfeeding policy in the working area of Cicalengka Community Health Center has not done well.

\section{Resources}

The resources mentioned by Edward that is supported by Meter, Horn, and Grindle in policy implementation includes human resources and financial resources (Massie in (Sagala, 2010)). According to Edward (1980) resources is a key factor in supporting the success of policy implementation. The resources meant here are include the adequacy of number and competency of the officers to do their job, adequacy of relevant information on how to implement the policy and how the factors of resources involved in the policy implementation.

The authority to guarantee that the policy is implemented as desired and the existence of the facility needed to implement the policy to be a functional service such as office buildings, tools, lands, and funds. The limitation of resources can be interpreted to be the ineffectiveness of law and regulation, low level of service, and undeveloped state of rational regulation 
(Supriadi, 2012). The variables of resources in this research are focused on three types, that is Human Resources, Financial Resources, and Facility Resources.

In Human Resources, the availability of officers is still not enough to implement this policy if we see the target of pregnant mothers in the Bandung Regency which are 75,000 people, but they only have one midwife is assigned in every village and there are still 10 villages that do not have any officers. The total number of midwives who are the Local Government employee and private employee are 800 people, and the number of paraji or traditional midwife is 800 people, with the coverage of birth at $87 \%$ and there are still $3 \%$ born with the help of paraji. Besides, there is a problem of many programs outside the Exclusive Breastfeeding that make the midwives have many duties all at once, that leads the program of Exclusive Breastfeeding to be left out. The competency from the perspective of education is already appropriate, but the problem is that there is a gap of knowledge between officers that have underwent training to be a Breastfeeding Counselor and those who have not. All of the informants stated that it is needed to have trainings for all of the officers inside the Community Health Center, however, it is constrained by the budget.

Second, is the budget. According to Edward III, budget limitedness will cause the quality of services that should be provided to the community is also limited (Akib, 2010). Budgets are required to fund the operationalization of the policy implementation, for instance to pay the salaries of policy implementers, the provision of facilities, program operationalization and many more (Ratri, 2014). In Bandung Regency, there are budget expenditures and local expenditures of Public Health Office which have been used to train Breastfeeding counselors. Meanwhile, in Community Health Center there are fund of Biaya Layanan Umum or Public Service Cost (PSC) and Biaya Operasional Kesehatan or Health Operational Cost (HOC). From the in-depth interviews, some employees do not know about the budget that support the Exclusive breastfeeding program. The absence of special budget is one of the causes of the innefectiveness of this policy implementation.

Third, is the facilities and infrastructure which are used for the operationalization of the policy implementation. It can be in the form of buildings, land, tools and any other facilities that make the provision of services in policy implementation becomes easier (Ratri, 2014). The facilities used in the promotion of Exclusive Breastfeeding are in the form of media counseling, flipcharts and leaflets, while the infrastructure provided is in the form of a breasfeeding corner. Overall, the role of Puskesmas in preparing the facility is good enough. However, the breastfeeding corner is not functioning properly because the design of the room is not attractive enough for the mother to use the breastfeeding corner, the lack of instruction to the mother to use the facilities provided, and the breastfeeding counselor room in which too far with child room.

The organizer of public facility in the form of Healthcare Facilities must support the success of Exclusive Breastfeeding program based on 10 (ten) steps to the success of breastfeeding described in Article 33 of Government Regulation on Breastfeeding, which includes:

a. developing a written policy on breastfeeding and communicate it to all healthcare staff;

b. training all healthcare staff in the skills of implementing the breastfeeding policies;

c. informing all pregnant women about the benefits and management of breastfeeding;

d. assisting the mothers in initiating early breastfeeding within at least the first 60 (sixty) minutes of childbirth;

e. helping the mothers how to breastfeed and maintaining their breastfeeding activity even if the mothers are separated from their baby;

f. giving only breast milk to the newborns unless there is a specific medical indication;

g. applying rooming-in maternal care to her baby for 24 (twenty four) hours

h. recommending the breastfeeding as the request from the baby;

i. not giving pacifier to the baby;

j. encouraging the establishment of breastfeeding support groups and refering the mothers to that group after being discharge from the Healthcare Facilities.

\section{Bureacratic Structure}

Bureaucracy becomes one of the most frequent organizations that implements the policy. In this research, the researched bureaucracy is the interagency coordination. In the process of policy implementation, the inter-agency coordination is required to avoid complex, twisted and long-term issues in order to implement the policy in a proper and quick way.

The concept of bureaucracy was first introduced by Max Weber, Dwijowijoto (2004: 63) in (Supriadi, 2012), stated that the organization is include a standardized, formal and procedured structure. Structure is a unity of a certain part or person that is formal. So, when it is being translated with another term, it is similar to a system.

As Wahab (2015) stated that coordination is not only how to communicate the information or establish a suitable organizational structure, coordination is also concerns the fundamental issue of the practice of the power implementation.

The Public Health Office of Bandung Regency has 
coordinated with Doctor Selasih to cooperate in the form of Breastfeeding counselor training procurement, but inter-agency cooperation such as with private companies, Petugas Lapangan Keluarga Berencana (Family Planning Field Officer), and Local Government has not been well established. At the level of Community Health Center, coordination efforts have been done between breastfeeding counselor midwives with fellow midwives and nutrition officers. In addition, coordination efforts are also carried out by teh Community Health Center to Cross Sector such as the Family Planning Field Officer, Pembinaan Kesejahteraan Keluarga (Fostering Family Welfare group), Community Leaders, and District level in form of non-formal information delivery on Exclusive Breeding policy. All those forms of coordination are only done nonformally because the Memorandum of Understanding has not been made.

Based on the bureaucratic structure factor, there is no clear SOP related to the implementation of breastfeeding counseling activity. It makes the breastfeeding counselor midwives perform breastfeeding counseling without any SOP guidance. Another study found that without SOP, a good implementation can not be expected because in the end of the day, the officers do the work according to their own understanding as there is no instrument that controls the quality of work (Purwaningrum, 2011). Aside from that, every activity must be accounted for by making a report as an evidence that the activity has been implemented and it is going to be used as a performance benchmark. The existence of SOP is intended to provide a clear, understandable, and writtenable concept on procedural documents in every activity (Alifah, 2012).

\section{Disposition}

Disposition includes the will, desire, and tendency of the policy actors to execute the policy seriously so that the goal of the policy can be achieved. A disposition will emerge among policy actors if it will benefit the organization and individual. This disposition process requires knowledge, understanding and deepening of the policy which leads to the action of acceptance, indifference and even refusal of a certain policy. The policy that being rejected by the implementer because of the implementing organization is not benefited with the existence of the policy, then it will lead to a disposition that hamper the policy implementation. In this research, the disposition that is observed is the attitude of the implementer in the form of commitment, support, and tendency of exclusive breastfeeding program implementation in the area of Cicalengka Community Health Center.

According to Edward (1980) in (Supriadi, 2012), if the policy wants to be implemented effectively, then the policy implementer must not only know what to do and have the ability to implement it, but they also must have a desire to implement the policy. Some implementers of
Exclusive Breastfeeding policy are committed to run the Exclusive Breastfeeding program in the form of counseling training, counseling, running the program well, creating Decree and SOP as well as ensuring that all mothers must be able to exclusively breastfeed.

Unfortunately, the delivered commitment has not been in written form, it is only an oral form. Therefore, there is no evidence that all employees are committed. While the mothers who exclusively breastfeed must commit to provide Exclusive Breastfeeding for 6 months and keep breastfeeding until the age of 2 years which also supported by maintaining a nutritious diet.

\section{Forms of Support}

According to (Lubis, 2000), family support is an important supporting factor for the Exclusive Breastfeeding program. Basically, family support provides emotional and psychological support for the mothers in breastfeeding. The result of the research shows that the whole group of mothers who do Exclusive Breastfeeding and mothers who do not do Exclusive Breastfeeding received support from their family in the form of advice that reminds about breastfeeding. The obstacles that make the mothers do not do Exclusive Breastfeeding are only a little milk came out, the baby does not want to suckle, and the mothers do not want to be bothered. All those things cause the family to support the mothers to give formula milk when the breast milk volume is a little. Another support received by the mothers are in the form of support from health cadres who always remind them and also the media that provides articles and advertisements on television about breastfeeding. While the support from health workers has done well by providing knowledge about Exclusive Breastfeeding and providing facilities for breastfeeding and counseling when there are obstacles when giving Exclusive Breastfeeding.

Table 3. Disposition of Exclusive Breastfeeding Program

\begin{tabular}{|c|c|c|}
\hline No. & Institution & Forms of Support \\
\hline 1. & $\begin{array}{l}\text { Public Health } \\
\text { Office of } \\
\text { Bandung } \\
\text { Regency }\end{array}$ & $\begin{array}{l}\text { - Creating a Local Regulation on } \\
\text { Maternal, Neonatal, Infant and Child } \\
\text { Health (MNICH) } \\
\text { - Helding a Breastfeeding Counselor } \\
\text { Training }\end{array}$ \\
\hline 2. & $\begin{array}{l}\text { Community } \\
\text { Health } \\
\text { Center/Health } \\
\text { Workers }\end{array}$ & $\begin{array}{l}\text { - Providing Breastfeeding Corner } \\
\text { - Initating an Early Breastfeeding } \\
\text { - Facilitating a Rooming-in Maternal Care } \\
\text { - Socializing about Breastfeeding when the } \\
\text { Mothers Come to Integrated Service Post } \\
\text { Every Month } \\
\text { - Helding a Children Class Thrice a Month } \\
\text { - Helding a Mother Class Once a Month }\end{array}$ \\
\hline 3. & Cadre & $\begin{array}{l}\text { - Reminding to give } \\
\text { Breastfeeding }\end{array}$ \\
\hline
\end{tabular}




\begin{tabular}{|c|c|c|}
\hline No. & Institution & Forms of Support \\
\hline 4. & Family & $\begin{array}{l}\text { - Reminding to give Exclusive } \\
\text { Breastfeeding } \\
\text { - Giving Formula Milk if the Breastmilk is } \\
\text { not Come Out }\end{array}$ \\
\hline 5. & Media & $\begin{array}{l}\text { - TV Advertisement } \\
\text { - Internet Articles } \\
\text { - Pink Book about Mother and Child } \\
\text { Health }\end{array}$ \\
\hline
\end{tabular}

In the Government Regulation No.33 of 2012, the community must support the success of Exclusive Breastfeeding programs either individually, in group, or organizationally. The support can be implemented through:

a. providing a thought contribution related to the determination of the policy and / or the implementation of the Exclusive Breastfeeding program;

b. disseminating information to the community regarding Exclusive Breastfeeding;

c. monitoring and evaluating the implementation of Exclusive Breastfeeding programs; and / or

d. providing time and place for mothers in giving Exclusive Breastfeeding.

The implementation of support from the community is done by referring to 10 (ten) steps to the success of breastfeeding for the community.

\section{CONCLUSIONS}

Based on the coverage of Exclusive Breastfeeding in Cicalengka Community Health Center, there are only $27 \%$ of mothers who exclusively breastfed. With that being said, it can be concluded that the implementation of Exclusive Breastfeeding policy in Cicalengka Community Health Center is not working properly. This is because the implementation component has not been worked in accordance with existing policy such as:

1) There has been no effective communication regarding the policy of Exclusive Breastfeeding in the area of Cicalengka Community Health Center, so we still find several phenomenons such as different information acceptance and the sustainability of information delivery which is not yet optimal. The socialization regarding the policy has not covered the overall target of Exclusive Breastfeeding policy.

2) The human resources and facilities at Cicalengka Community Health Center have been adequate in quantity, but there is no commitment of the human resources to implement the policy, and there is no policy instrument as well as budget support.

3) The bureaucracy structure at Cicalengka Community Health Center in the form of interagency coordination has been conducted, but it still lack in the creation of Memorandum of
Understanding of the cooperation. Some officers execute the activities according to their ability, not based on existing SOP.

4) The disposition at Cicalengka Community Health Center is in the form of health officer, family, media, cadres and Public Health Office of Bandung Regency attitudes who have supported and committed to the successful implementation of Exclusive Breastfeeding policy, but not fully supported by family attitudes when facing the situation of only a little milk came out.

\section{RECOMMENDATIONS}

Based on the conclusion of the researchers, there are several recommendations proposed:

a. For The Public Health Office

1) The Public Health Office of Bandung Regency should conduct a monitoring and evaluation effort on the implementation of Exclusive Breastfeeding policy in healthcare facilities such as but not limited to Community Health Center by conducting direct supervision to the field;

2) The Public Health Office of Bandung Regency should perform socialization to healthcare facilities located in Bandung Regency consistently;

3) Socializing of Exclusive Breastfeeding policy to other institutions such as private companies and other government agencies through a circular letter accompanied by Exclusive Breastfeeding Handbook and proven by an MoU between agencies;

4) Conducting a training of Breastfeeding Counselors gradually, so that every healthcare facility has Breastfeeding counselor;

5) Conducting self-assessment and program evaluation continuously;

6) Allocating budget for the Exclusive Breastfeeding program on the activity budget 2018, so that its implementation do not experience funding constraint;

7) Improving the commitment of the leaders in the Exclusive Breastfeeding policy implementation through the establishment of a special team of Exclusive Breastfeeding program as a form of an oversee of the policy.

b. For Cicalengka Community Health Center

1) Conducting direct socialization from breastfeeding counselor to the officers who directly play socialization role to society such as but not limited to midwives;

2) Conducting socialization, monitoring and evaluation directly to the community, especially breastfeeding mothers, so that the Exclusive Breastfeeding policy is delivered 
properly;

3) Establishing a support group of mothers who exclusively breastfeed in each village as a means of information for new breastfeeding mothers;

4) The support and commitment from all employees in Cicalengka Community Health Center are needed in the implementation of Exclusive Breastfeeding policy;

5) Utilizing social media as a means of communication in the delivery of information related to Exclusive Breastfeeding policy.

c. For Policy Researchers

1) Establishing special regulations in order to ensure that the purpose and objectives of the policies made by the government are truly communicated to the people;

2) Conducting research related to the implementation of Exclusive Breastfeeding policy in depth and comprehensively of each sector involved.

\section{REFERENCES}

Akib, H. (2010). Implementasi Kebijakan: Apa, Mengapa dan Bagaimana. Jurnal Administrasi Publik, Volume 1 $N$.

Alifah, N. (2012). Analisis sistem manajemen program pemberian ASI eksklusif di wilayah kerja Puskesmas Candilama Kota Semarang. Kesehatan Masyarakat, 1(2), 97-107.

Depkes. (2013). Riset Kesehatan Dasar. Jakarta.

Heymann, J., Raub, A., \& Earle, A. (2013). Breastfeeding policy: a globally comparative analysis. Bull World Health Organ, 91, 398-406. https://doi.org/10.2471/BLT.12.109363.

Kemenkes, R. (2014). Pusat Data dan Informasi Kementrian Kesehatan. Retrieved from www.depkes.go.id/resources/download/pusdatin/infod atin/infodatin-asi.pdf.

Kementerian Kesehatan RI. (2017). Data dan Informasi Profil Kesehatan Indonesia 2016. Kementerian Kesehatan RI, 100. Retrieved from http://www.depkes.go.id/resources/download/pusdatin /lain-lain/Data dan Informasi Kesehatan Profil Kesehatan Indonesia 2016 - smaller size - web.pdf.

Lubis, N. U. (2000). Manfaat Pemakaian ASI Eksklusif. Majalah Cermin Dunia Kedokteran, 26.

Purwaningrum, Y. (2011). Analisis implementasi pemeriksaan kadar haemoglobin dalam pelayanan antenatal di Puskesmas Kabupaten Jember Provinsi Jawa Timur. Universitas Diponegoro.

Ratri, D. (2014). Implementasi Peraturan Walikota Nomor 36 Tahun 2013 Tentang Kebijakan Kota Layak Anak. Jurnal Mahasiswa Ilmu Pemerintahan.

Roesli, U. (2013). Panduan Inisiasi Menyusu Dini Plus ASI Eksklusif. Jakarta: Pustaka Bunda.

Sagala, S. (2010). Managemen Strategik dalam Peningkatan Mutu Pendidikan. Bandung: Alfabeta.

Sudarwati, T. (2012). Implementasi Kebijakan Pendidikan Lingkungan Hidup Sekolah Menengah Atas Negeri 11 Semarang Menuju Sekolah Adiwiyata. Universitas Diponegoro.
Supriadi, A. (2012). Analisis Prakondisi Implementasi Kebijakan Peningkatan Kompetensi Guru. Jurnal Pendidikan Dan Pembelajaran (JPP).

Suradi, R. (1989). Peranan Lingkungan Untuk Menunjang Keberhasilan Laktasi. Jakarta: Bunga Rampai Menyusui dan Rawat Gabung.

WHO. (2015). Worldwide Country Situation Analysis: Response to Antimicrobial Resistance. Geneva. 